\title{
Response of green manure species and millet cultivars to different populations of Meloidogyne javanica
}

\author{
Lana Chidichima ${ }^{1}$, Angélica Miamoto ${ }^{1 *}$, Luanna Rinaldi $^{1}$, Arlindo Corrêia $^{2}$, and Cláudia Dias-Arieira ${ }^{3}$ \\ ${ }^{1}$ Universidade Estadual de Maringá, Pós-Graduação em Agronomia, Maringá, Av. Colombo, № 5790 - Bloco J45, 2 Piso, 87020-900, \\ Maringá-PR, Brasil. *Corresponding author (angelicamiamoto@gmail.com). \\ ${ }^{2}$ Pontifícia Universidade Católica do Paraná, Departamento de Agronomia Toledo, Av. União 500, Villa Becker, Toledo, PR, Brasil. \\ ${ }^{3}$ Universidade Estadual de Maringá, Departamento de Ciências Agrárias, Av. Ãngelo Moreira da Fonseca 1800, Parque Danielle, \\ Umuarama, PR, Brasil.
}

Received: 7 December 2020; Accepted: 9 March 2021; doi:10.4067/S0718-58392021000300310

\begin{abstract}
The use of non-host cover crops is a key strategy for controlling root-knot nematodes in infested fields. However, pathogenicity of nematodes to cover crops may vary between populations and localities. This study assessed the response of green manure species and millet (Pennisetum glaucum (L.) R.Br.) cultivars to four populations of Meloidogyne javanica (denominated Mj-2, Mj-3, Mj-6 and Mj-7). Seedlings of radish (Raphanus sativus L.), pigeon pea (Cajanus cajan (L.) Huth) 'IAPAR 43', buckwheat (Fagopyrum esculentum Moench) 'IPR 92-Altar' and millet 'BRS 1501', 'ADR 300' and 'ADR 500' were inoculated with 1000 eggs and second-stage juveniles of M. javanica. Soybean (Glycine max (L.) Merr.) 'M6210 IPRO' was used as control. At $60 \mathrm{~d}$ after inoculation, plants were evaluated for root fresh weight, gall index (GI), number of nematodes per gram of root and reproduction factor (RF). For GI, Mj-3 and Mj-6 were the most aggressive to soybean $(\mathrm{GI}=5.0)$. In pigeon pea, $\mathrm{Mj}-7$ resulted in the highest GI (3.5). Radish had the lowest GI (0.67) with $\mathrm{Mj}-2$. For buckwheat, $\mathrm{Mj}-3$ was the most aggressive population, with a GI of 4.50. Mj-3 and Mj-7 resulted in the highest GI in 'ADR 300', and Mj-6 and Mj-7 in 'ADR 500'. The reproductive ability of nematode populations differed between hosts. Mj-2 was the most pathogenic to 'ADR 300' $(\mathrm{RF}=10.88), \mathrm{Mj}-3$ to buckwheat $(\mathrm{RF}=53.46)$ and radish $(\mathrm{RF}=4.81), \mathrm{Mj}-6$ to 'ADR 500' $(\mathrm{RF}=19.58)$ and $\mathrm{Mj}-7$ to pigeon pea $(\mathrm{RF}=2.99)$ and 'BRS 1501 ' $(\mathrm{RF}=15.05)$. Soybean was susceptible to all $M$. javanica populations $(\mathrm{RF}=33.69$ to 257.22$)$. Green manure species and millet cultivars varied in their responses to $M$. javanica populations of different origins.
\end{abstract}

Key words: Aggressiveness, cover crops, Pennisetum glaucum, root-knot nematode.

\section{INTRODUCTION}

Meloidogyne javanica (Treub, 1885) Chitwood (Tylenchida: Heteroderidae) is one of the most important plant-parasitic nematodes because of its wide host range and geographical distribution. This pathogen can substantially limit the yield of grains, vegetables and fruits (Oliveira et al., 2017). In soybean, M. javanica can cause losses of up to 30\% (Dias et al., 2010). A complex interaction occurs between plant and pathogen. The establishment of nematode feeding sites in the host root system causes cell hyperplasia and hypertrophy (Ferraz and Brown, 2016), leading to gall formation in roots, wilting during the hottest hours of the day and leaf chlorosis (Oliveira et al., 2017).

An efficient strategy to manage nematodes is crop rotation with antagonistic, non-host or resistant plants (Debiasi et al., 2016). When used as cover crops, rotation crops or intercrops, millet (Pennisetum glaucum (L.) R.Br.), buckwheat (Fagopyrum esculentum Moench), radish (Raphanus sativus L.) and pigeon pea (Cajanus cajan (L.) Huth) effectively controlled nematode populations, preventing infection and/or nematode multiplication (Araújo Filho et al., 2010; Miamoto 
et al., 2016). Although these crops have potential against nematodes, their susceptibility may vary depending on nematode population, climate and soil conditions (Silva et al., 2014; Castagnone-Sereno et al., 2019). Nematode pathogenicity is also determined by environmental conditions and genetic mutations (Castagnone-Sereno et al., 2019). Because $M$. javanica reproduces by mitotic parthenogenesis, it is likely that mechanisms other than those related to genes contribute to the differences in virulence observed between populations of the same species (Barbary et al., 2015).

Identification of the aggressiveness and pathogenicity of nematode populations is crucial for the development of effective control strategies. This study aimed to assess the response of green manure species and millet cultivars to different populations of M. javanica.

\section{MATERIAL AND METHODS}

\section{Collection and maintenance of nematode populations}

Samples of soil and plant roots with galls were collected between March and May 2017 in Formosa do Rio Preto, Bahia (Mj-2 and Mj-6); Londrina, Paraná (Mj-3); and Nova Maringá, Mato Grosso (Mj-7), Brazil. Then, 3 L soil and roots from each locality were placed in pots and sown with four seeds of tomato (Solanum lycopersicum L.) 'Santa Clara' or okra (Abelmoschus esculentus (L.) Moench) 'Santa Cruz', to promote nematode (Meloidogyne javanica) multiplication. Pots were kept in greenhouse ( $23^{\circ} 24^{\prime} 17.39^{\prime \prime} \mathrm{S}, 51^{\circ} 56^{\prime} 27.00^{\prime \prime} \mathrm{W} ; 596 \mathrm{~m}$ a.s.1.) for $60 \mathrm{~d}$. Irrigation was applied as needed.

After $60 \mathrm{~d}$ of cultivation, some plants were collected for isoenzymatic analysis and inoculum purification. Twenty milky-white M.javanica females and their egg masses were collected from each sample using a pair of fine-tipped forceps and a stereoscope microscope. Females were transferred to capillary tubes containing extraction buffer (Carneiro and Almeida, 2001), macerated with a needle, mixed with bromophenol blue and loaded onto a polyacrylamide gel. A sample of M. javanica was used as an internal standard for phenotypic comparison.

One egg mass of each $M$. javanica female was inoculated on tomato, individually. Tomato plants were transplanted to pots containing $2 \mathrm{~L}$ autoclaved soil $\left(120^{\circ} \mathrm{C}\right.$ for $\left.2 \mathrm{~h}\right)$ and kept under greenhouse conditions for 5 -mo for nematode multiplication.

\section{Response of green manure species and millet cultivars to $M$. javanica}

Two experiments were conducted under greenhouse conditions using a $4 \times 4$ factorial design with six replicates. In the first experiment, soybean (Glycine max (L.) Merr.) 'M6210 IPRO' (control) and three green manure species were inoculated with four populations of M. javanica: pigeon pea (Cajanus cajan (L.) Huth) 'IAPAR 43', radish (Raphanus sativus L.) and buckwheat (Fagopyrum esculentum Moench) 'IPR 92-Altar'. The second experiment comprised soybean 'M6210 IPRO' (control) and millet (Pennisetum glaucum (L.) R.Br.) 'BRS1501', 'ADR 300' and 'ADR 500' inoculated with four M. javanica populations. Experiments were performed between April and June 2019, when the average minimum temperature was $16.2{ }^{\circ} \mathrm{C}$ and average maximum $26.3^{\circ} \mathrm{C}$.

Seeds were sown in pots containing commercial substrate (Horta 2, MecPlant, Telêmaco Borba, Paraná, Brazil). Fifteen days after sowing, seedlings were transplanted to expanded polystyrene containers filled with $500 \mathrm{~mL}$ substrate $\left(1: 1\right.$ mixture of clay soil and sand autoclaved for $2 \mathrm{~h}$ at $\left.120^{\circ} \mathrm{C}\right)$. At the time of transplant, plants were inoculated with 3 $\mathrm{mL}$ suspension containing 1000 eggs and eventual second-stage juveniles of $M$.javanica. Nematodes were extracted from roots according to Boneti and Ferraz (1981), and the inoculum was adjusted using a Peters counting chamber under a light microscope.

At $60 \mathrm{~d}$ after sowing, plants were collected and the roots washed, blotted dry with paper towels and weighed to obtain fresh root weight. Galls were counted and the gall index (GI) was rated on a scale of 1 to 5 , where 0 indicates absence of galls, 1 indicates the presence of 1 to 2 galls, 2 represents 3 to 10 galls, 3 represents 11 to 30 galls, 4 represents 31 to 100 galls and 5 indicates the presence of more than 100 galls per plant (Taylor and Sasser, 1978). Nematodes were extracted from roots according to Boneti and Ferraz (1981) and counted under a light microscope to obtain the total number of nematodes, which was divided by the root fresh weight to obtain the nematode population density (number of nematodes per gram of root). The reproduction factor (RF) was calculated as the total number of nematodes divided by the inoculum amount (Oostenbrink, 1966). Plants with a RF $<1$ were considered resistant and those with $\mathrm{RF} \geq 1$ were considered susceptible to the nematode. 


\section{Statistical analysis}

Data were subjected to ANOVA followed by Tukey's test at $\mathrm{P}<0.05$. When necessary, data were transformed to $\sqrt{ }(x+1)$ to meet normality assumptions based on the Shapiro-Wilk test. Statistical analyses were performed using the ExpDes.pt package (Ferreira et al., 2011) of R version 3.5.1 (R Core Team, 2018).

\section{RESULTS AND DISCUSSION}

\section{Green manure species}

The aggressiveness of $M$. javanica populations to green manure species varied for buckwheat and soybean (Table 1). Host $\times$ Nematode population interaction effects were significant for all parameters. Nematological parameters were high in soybean, confirming the crop suitability (Table 1$)$. $\mathrm{Mj}-3$ and $\mathrm{Mj}-6$ were the most aggressive to soybean $(\mathrm{GI}=5.0$ ), followed by $\mathrm{Mj}-7$ ( $\mathrm{GI}=3.5)$ and $\mathrm{Mj}-2(\mathrm{GI}=2.67)$. $\mathrm{Mj}-2$ had the lowest population density ( 9813 nematodes $\mathrm{g}^{-1}$ root) in the control; all other population densities were higher than 38000 nematodes $\mathrm{g}^{-1}$ root. Although the $\mathrm{RF}$ of $\mathrm{Mj}-2$ on soybean was high (33.69), it was still lower than that of the other populations (mean $\mathrm{RF}=221$; Table 1).

In pigeon pea, Mj-7 infection resulted in the highest GI (3.5); and $\mathrm{Mj}-6$, in the lowest (GI = 0) (Table 1). Population density and RF did not vary between populations. Pigeon pea was susceptible to $\mathrm{Mj}-2(\mathrm{RF}=2.56)$ and $\mathrm{Mj}-7(\mathrm{RF}=2.99)$ and resistant to $\mathrm{Mj}-3(\mathrm{RF}=0.58)$ and $\mathrm{Mj}-6(\mathrm{RF}=0.65)$.

The resistance of pigeon pea 'IAPAR-43' to M. javanica was previously reported (Miamoto et al., 2016). Its use as a rotation crop with soybean is indicated because of its low susceptibility to Pratylenchus zeae Graham and P. brachyurus (Godfrey) Filipjev \& Schuurmans Stekhoven (Santana-Gomes et al., 2019). However, our results showed that caution must be taken when using pigeon pea to control M. javanica, because, although its RF was lower than that of soybean, pigeon pea was susceptible to $\mathrm{Mj}-2$ and $\mathrm{Mj}-7$.

The ability of $M$. javanica to infect a wide variety of hosts makes it difficult to select rotation crops for nematode control. Plants that are considered susceptible (RF $>1$ ) should not be disregarded if their RF is lower than that of highly susceptible plants, such as soybean and maize, and especially if they provide other benefits, including $\mathrm{N}$ fixation, competition with weeds and high production of organic matter (Debiase et al., 2016; Santana-Gomes et al., 2019).

Table 1. Gall index, nematode population density and reproduction factor of Meloidogyne javanica populations inoculated in green manure species and soybean (control).

\begin{tabular}{|c|c|c|c|c|}
\hline \multirow[t]{2}{*}{ Population } & \multicolumn{4}{|c|}{ Gall index } \\
\hline & Pigeon pea & Radish & Buckwheat & Soybean \\
\hline $\mathrm{Mj}-2$ & $1.33 \mathrm{bAB}$ & $0.67 \mathrm{bB}$ & $2.00 \mathrm{bA}$ & $2.67 \mathrm{bA}$ \\
\hline $\mathrm{Mj}-3$ & $1.67 \mathrm{bB}$ & $3.17 \mathrm{aAB}$ & $4.50 \mathrm{aA}$ & $5.00 \mathrm{aA}$ \\
\hline Mj-6 & $0.00 \mathrm{cC}$ & $2.17 \mathrm{aB}$ & $4.00 \mathrm{aA}$ & $5.00 \mathrm{aA}$ \\
\hline $\mathrm{Mj}-7$ & $3.50 \mathrm{aA}$ & $2.50 \mathrm{aA}$ & $3.50 \mathrm{abA}$ & $3.50 \mathrm{abA}$ \\
\hline \multirow[t]{2}{*}{$\mathrm{CV}, \%$} & \multicolumn{4}{|c|}{14.83} \\
\hline & \multicolumn{4}{|c|}{ Population density, nematodes $\mathrm{g}^{-1}$ root } \\
\hline $\mathrm{Mj}-2$ & $3889 \mathrm{aAB}$ & $1438 \mathrm{aB}$ & $1116 \mathrm{bB}$ & 9813bA \\
\hline $\mathrm{Mj}-3$ & $94 \mathrm{aC}$ & $3124 \mathrm{aC}$ & $13316 \mathrm{aB}$ & $40775 \mathrm{aA}$ \\
\hline $\mathrm{Mj}-6$ & $184 \mathrm{aB}$ & $2076 \mathrm{aB}$ & $1773 b B$ & $45161 \mathrm{aA}$ \\
\hline $\mathrm{Mj}-7$ & $2987 \mathrm{aB}$ & $2614 \mathrm{aB}$ & $4522 \mathrm{abB}$ & $38422 \mathrm{aA}$ \\
\hline \multirow[t]{2}{*}{$\mathrm{CV}, \%$} & \multicolumn{4}{|c|}{48.79} \\
\hline & \multicolumn{4}{|c|}{ Reproduction factor } \\
\hline $\mathrm{Mj}-2$ & $2.56 \mathrm{aA}$ & $1.69 \mathrm{aA}$ & $2.94 \mathrm{bA}$ & $33.69 \mathrm{bA}$ \\
\hline $\mathrm{Mj}-3$ & $0.58 \mathrm{aC}$ & $4.81 \mathrm{aC}$ & $53.46 \mathrm{aB}$ & $257.22 \mathrm{aA}$ \\
\hline Mj-6 & $0.65 \mathrm{aB}$ & $2.55 \mathrm{aB}$ & $5.85 \mathrm{bB}$ & $221.93 \mathrm{aA}$ \\
\hline $\mathrm{Mj}-7$ & $2.99 \mathrm{aB}$ & $2.95 \mathrm{aB}$ & $7.71 \mathrm{bB}$ & $224.90 \mathrm{aA}$ \\
\hline $\mathrm{CV}, \%$ & \multicolumn{4}{|c|}{55.73} \\
\hline
\end{tabular}

For each parameter, means followed by the same lowercase letter in a column or uppercase letter in a row did not differ $(\mathrm{P}>0.05)$ by Tukey's test. Data were transformed to $\sqrt{ }(\mathrm{x}+1)$ before analysis.

CV: Coefficient of variation. 
Radish had the lowest GI (0.67) when inoculated with $\mathrm{Mj}$-2, indicating that this population was the least aggressive to the crop (Table 1). Population densities did not differ, and the RF ranged from $1.69(\mathrm{Mj}-2)$ to $4.81(\mathrm{Mj}-3)$. Previous studies found that M. javanica had an RF of 2.14, 2.44 and 2.20 on radish in three different seasons (Rosa et al., 2013). As observed for pigeon pea, the RF on radish was much lower than that on soybean (33.69 to 257.22). Radish can grow in weak and acid soils, contributing to soil decompaction, nutrient cycling (Krenchinski et al., 2018) and control of Heterodera glycines Ichinohe and Rotylenchulus reniformis Lindford \& Oliveira (Inomoto and Asmus 2009).

For buckwheat, Mj-3 was the most aggressive population, with a GI of 4.50, an RF of 53.46 and a population density of 13316 nematodes $\mathrm{g}^{-1}$ root (Table 1). Values of RF of the other nematode populations ranged from 2.94 to 7.71 . The susceptibility of buckwheat to $M$. javanica shows that care must be taken when using the crop as a control strategy. The literature lacks information about the plant's response to nematodes, precluding comparison of results. Aissani et al. (2018) showed that polyphenols, fagopyrine and aldehydes extracted from buckwheat had nematicidal effects on $M$. incognita (Kofoid \& White, 1919) Chitwood. This plant is considered a green manure species because it regenerates depleted soils, controls weeds and is tolerant to low soil pH and high $\mathrm{Al}$ levels ( $\mathrm{Al}^{3+}$ ) (Klein et al., 2010).

When comparing the different crops, we observed that soybean and buckwheat had the highest GI, except when inoculated with Mj-7; plants inoculated with this population did not differ in GI (Table 1). Nematode population density was highest in soybean for all $M$. javanica populations. In pigeon pea, radish and buckwheat, $\mathrm{Mj}-3$ had the highest population density. The population densities of $\mathrm{Mj}-2, \mathrm{Mj}-6$ and $\mathrm{Mj}-7$ did not differ among the crops. Soybean had the highest RF for all populations, except for Mj-2, which did not differ of the other crops (Table 1). On buckwheat, Mj-3 showed the highest RF.

Variation in nematode pathogenicity and virulence is not uncommon. This characteristic increases the difficulty in controlling root-knot nematodes using crop rotation and resistant plants (Bucki et al., 2017). Potato cultivars showed different susceptibilities to M. javanica populations (Lima-Medina et al., 2017). Mattos et al. (2016) evaluated the aggressiveness of M. javanica and M. morocciensis Rammah \& Hirschmann populations extracted from native vegetation and soybean to different soybean genotypes and observed that nematodes extracted from soybean fields were more aggressive than those extracted from native plants. Such studies demonstrate the importance of using aggressive nematode populations to test the susceptibility of resistant plants and rotation crops (Lima-Medina et al., 2017), since a crop that is resistant to a nematode population may be susceptible to another. Therefore, it is necessary to investigate the virulence characteristics of nematode populations occurring in each locality (Bucki et al., 2017).

Meloidogyne javanica reproduces by mitotic parthenogenesis, sharing the same genetic heritage as its descendants. However, phenotypic variations may occur when individuals are exposed to unfavorable environments, such as resistant plants (Barbary et al., 2015). Thus, virulent specimens may descend from avirulent nematodes, contributing to the maintenance of nematodes in the field over the generations (Castagnone-Sereno et al., 2019). Sharma et al. (2018) argued that adaptive genetic variation is an evolutionary force that promotes morphological, physiological and metabolic adaptations in the face of changes to the environment.

\section{Millet cultivars}

Significant interaction effects between $M$. javanica populations and millet cultivars were observed for all parameters. GI values did not vary between populations in 'BRS 1501' and soybean (Table 2). Mj-3 and Mj-7 resulted in the highest GI in 'ADR 300', and Mj-6 and Mj-7 in 'ADR 500'.

Nematode population density did not vary between populations in 'BRS 1501' and 'ADR 300'. In 'ADR 500' and soybean, Mj-6 had the highest population density. In soybean, the population density of Mj-3 did not differ from that of Mj-6 (Table 2).

The RF of M. javanica populations on 'BRS 1501' or 'ADR 300' did not differ significantly, although some values were five times higher than others (Table 2). On 'BRS 1501', RF ranged from 2.73 (Mj-3) to 15.05 (Mj-7); and on 'ADR 300', from 2.36 (Mj-6) to 10.88 (Mj-2). 'ADR 500' had the highest RF (about 19) when inoculated with Mj-6 and Mj-7, much higher than when inoculated with Mj-2 (3.28). On soybean, the highest RF values were obtained with Mj-3 (152.91) and Mj-6 (124.01), higher than those obtained with Mj-2 (43.31) and Mj-7 (72.66).

The variation in susceptibility between millet cultivars corroborates previous studies on BRS 1501 . The cultivar was found to be resistant to M.javanica in a study conducted by Gabriel et al. (2018) but susceptible to M. javanica in a study by Inomoto et al. (2008). 
Table 2. Gall index, nematode population density and reproduction factor of Meloidogyne javanica populations inoculated in millet 'BRS 1501', ‘ADR 300', 'ADR 500' and soybean (control).

\begin{tabular}{|c|c|c|c|c|}
\hline \multirow[t]{2}{*}{ Population } & \multicolumn{4}{|c|}{ Gall index } \\
\hline & BRS 1501 & ADR 300 & ADR 500 & Soybean \\
\hline $\mathrm{Mj}-2$ & $0.43 \mathrm{aB}$ & $1.00 \mathrm{abB}$ & $0.86 \mathrm{bB}$ & $2.71 \mathrm{aA}$ \\
\hline $\mathrm{Mj}-3$ & $1.00 \mathrm{aB}$ & $1.71 \mathrm{aB}$ & $1.43 \mathrm{bB}$ & $4.86 \mathrm{aA}$ \\
\hline $\mathrm{Mj}-6$ & $0.43 \mathrm{aB}$ & $0.14 \mathrm{bB}$ & $3.43 \mathrm{aA}$ & $5.00 \mathrm{aA}$ \\
\hline $\mathrm{Mj}-7$ & $1.57 \mathrm{aB}$ & $1.43 \mathrm{aB}$ & $2.86 \mathrm{aAB}$ & $3.71 \mathrm{aA}$ \\
\hline \multirow[t]{2}{*}{$\mathrm{CV}, \%$} & \multicolumn{4}{|c|}{19.45} \\
\hline & \multicolumn{4}{|c|}{ Population density, nematodes $\mathrm{g}^{-1}$ root } \\
\hline $\mathrm{Mj}-2$ & $464 \mathrm{aB}$ & $1323 \mathrm{aB}$ & $346 \mathrm{bB}$ & $17429 \mathrm{bA}$ \\
\hline $\mathrm{Mj}-3$ & $369 \mathrm{aB}$ & $933 \mathrm{aB}$ & 860abB & $38793 \mathrm{aA}$ \\
\hline $\mathrm{Mj}-6$ & $389 \mathrm{aBC}$ & $160 \mathrm{aC}$ & $3430 \mathrm{aB}$ & $38115 \mathrm{aA}$ \\
\hline $\mathrm{Mj}-7$ & $1753 \mathrm{aB}$ & $257 \mathrm{aB}$ & $3356 \mathrm{abB}$ & 19930bA \\
\hline \multirow[t]{2}{*}{$\mathrm{CV}, \%$} & \multicolumn{4}{|c|}{40.96} \\
\hline & \multicolumn{4}{|c|}{ Reproduction factor } \\
\hline $\mathrm{Mj}-2$ & $3.00 \mathrm{aB}$ & $10.88 \mathrm{aB}$ & $3.28 \mathrm{bB}$ & $43.31 \mathrm{bA}$ \\
\hline $\mathrm{Mj}-3$ & $2.73 \mathrm{aB}$ & $5.70 \mathrm{aB}$ & $6.86 \mathrm{abB}$ & $152.91 \mathrm{aA}$ \\
\hline $\mathrm{Mj}-6$ & $3.03 \mathrm{aC}$ & $1.36 \mathrm{aC}$ & $19.58 \mathrm{aB}$ & $124.01 \mathrm{aA}$ \\
\hline $\mathrm{Mj}-7$ & $15.05 \mathrm{aB}$ & $1.98 \mathrm{aB}$ & $19.45 \mathrm{aB}$ & $72.66 \mathrm{bA}$ \\
\hline $\mathrm{CV}, \%$ & \multicolumn{4}{|c|}{37.93} \\
\hline
\end{tabular}

For each parameter, means followed by the same lowercase letter in a column or uppercase letter in a row did not differ $(\mathrm{P}>0.05)$ by Tukey's test. Data were transformed to $\sqrt{ }(\mathrm{x}+1)$ before analysis.

$\mathrm{CV}$ : Coefficient of variation.

Soybean had the highest GI compared to other crops, except 'ADR 500', from which it did not differ when inoculated with Mj-6 (Table 2). Population density and RF were higher in soybean than in millet cultivars.

The RF of Mj-2 ranged from 3.00 on 'BRS 1501' to 43.31 on soybean (Table 2). The discrepancy between these crops was even higher with Mj-3: the RF value ranged from 2.73 ('BRS 1501') to 152.91 (soybean). The RF of Mj-6 ranged from 1.36 ('ADR 300') to 124.01 (soybean), and that of Mj-7 ranged from 1.98 ('ADR 300') to 72.66 (soybean).

Millet (cultivar not specified) and millet 'ADR 300' and 'ADR 500' were shown to be susceptible to M. javanica (Carneiro et al., 2006; Gabriel et al., 2018) but resistant to P. brachyurus and R. reniformis (Gardiano et al., 2012; Neves, 2013). The plant has interesting characteristics for use as a cover crop, such as rapid growth, vigorous root system, high tillering potential, high nutrient cycling ability and pathogen resistance (Padovan et al., 2012). The variability in the aggressiveness of $M$. javanica populations to millet cultivars is likely due to genetic alterations in nematodes, which influences how these individuals respond to plant defense mechanisms (Castagnone-Sereno, 2002). Therefore, it is important to periodically monitor the root-knot nematode population in areas under millet cultivation. Added to this, the need for additional care by seed companies, in evaluating new genetic materials against different populations of the same species of nematode.

\section{CONCLUSIONS}

Green manure species and millet cultivars varied in their responses to Meloidogyne javanica populations of different origins. Mj-2 was the most aggressive to millet 'ADR 300', Mj-3 to buckwheat and radish, Mj-6 to millet 'ADR 500' and Mj-7 to pigeon pea and millet 'BRS 1501'. Soybean was susceptible to all M. javanica populations.

\section{ACKNOWLEDGEMENTS}

The authors thank the Brazilian Federal Agency for Support and Evaluation of Graduate Education (CAPES) for the Masters scholarship granted to LPSC and the Brazilian National Council for Scientific and Technological Development (CNPq) for the Research Productivity Fellowship awarded to CRDA. 


\section{REFERENCES}

Aissani, N., Balti, R., and Sebai, H. 2018. Antiparasitic activity of Fagopyrum esculentum Moench on Meloidogyne incognita. Journal of Analytical Toxicology 1:1-6.

Araújo Filho, J.V., Inomoto, M.M., Godoy, R., e Ferraz, L.C.C.B. 2010. Resistência de linhagens de feijão-guandu a Meloidogyne javanica. Nematologia Brasileira 4:75-81.

Barbary, A., Djian-Caporalino, C., Palloix, A., and Castagnone-Sereno, P. 2015. Host genetic resistance to root-knot nematodes, Meloidogyne spp., in Solanaceae: From genes to the field. Pest Management Science 1:1591-1598.

Boneti, J.I.S., e Ferraz, S. 1981. Modificação do método de Hussey e Barker para extração de ovos de Meloidogyne exigua de raízes de cafeeiro. Fitopatologia Brasileira 6:553.

Bucki, P., Paran, I., Ozalvo, R., Iberkleid, I., Ganot, L., and Miyara, S.B. 2017. Pathogenic variability of Meloidogyne incognita populations occurring in pepper-production greenhouse in Israel Toward $\mathrm{Mel}, \mathrm{Me} 3$ and $\mathrm{N}$ pepper resistance genes. Plant Disease 101:1391-1401.

Carneiro, R.D.G., e Almeida, M.R.A. 2001. Técnica de eletroforese usada nos estudos de enzimas dos nematoides de galhas para identificação de Espécies. Nematologia Brasileira 25:35-44.

Carneiro, R.G., Moritz, M.P., Mônaco, A.P.A., Nakamura, K.C., e Scherer, A. 2006. Reação de milho, sorgo e milheto a Meloidogyne incognita, M. javanica e M. paranaensis. Nematologia Brasileira 31:10-13.

Castagnone-Sereno, P. 2002. Genetic variability of nematodes: threat to the durability of plant resistance genes? Euphytica 124:193-199.

Castagnone-Sereno, P., Mulet, K., Danchin, E.G.J., Koutsovoulos, G.D., Karaulic, M., Rocha, M., et al. 2019. Gene copy number variations as signatures of adaptive evolution in the parthenogenetic, plant-parasitic nematode Meloidogyne incognita. Molecular Ecology 28:2559-2572.

Debiasi, H., Franchini, J.C., Dias, W.P., Ramos Junior, E.U., e Balbinot Junior, A.A. 2016. Práticas culturais na entressafra da soja para o controle de Pratylenchus brachyurus. Pesquisa Agropecuária Brasileira 51:1720-1728.

Dias, W.P., Freitas, V.M., Ribeiro, N.R., Moita, A.W., Homechin, M., Parpinelli, N.M.B., et al. 2010. Reação de genótipos de soja a Meloidogyne enterolobii e M. ethiopica. Nematologia Brasileira 34:220-225.

Ferraz, L.C.C.B., e Brown, D.J.F. (orgs.) 2016. Nematologia de plantas: fundamentos e importância. Norma Editora, Manaus, Amazonas, Brasil.

Ferreira, E.B., Cavalcanti, P.P., and Nogueira, D.A. 2011. Experimental Designs: um pacote R para análise de experimentos. Revista da Estatística da UFOP 1:1-9.

Gabriel, M., Kulczynski, S.M., Belle, C., Kirsch, V.G., e Calderan-Bisognin, E.A. 2018. Reação de gramíneas forrageiras a Meloidogyne spp. e Pratylenchus brachyurus. Nematropica 48:155-163.

Gardiano, C.G., Krzyzanowski, A.A., e Saab, O.J.A. 2012. Hospedabilidade de plantas melhoradoras de solo à Rotylenchulus reniformis Linford e Oliveira (1940). Arquivos do Instituto Biológico 79:313-317.

Inomoto, M.M., Antedomênico, S.R., Santos, V.P., Silva, R.A., e Almeida, E.G.C. 2008. Avaliação em casa e vegetação do uso de sorgo, milheto e crotalária no manejo de Meloidogyne javanica. Tropical Plant Pathology 33:125-129.

Inomoto, M.M., e Asmus, G.L. 2009. Culturas de cobertura e de rotação devem ser plantas não hospedeiras de nematoides. Visão Agrícola 6:112-116.

Klein, V.A., Navarini, L.L., Baseggio, M., Madalosso, T., e Costa, L.O. 2010. Trigo mourisco: uma planta de triplo propósito e uma opção para rotação de culturas em áreas sob plantio direto. [Online] Revista Plantio Direto. Available at http://www.plantiodireto.com.br/?body=cont_int\&id=991 (accessed 26 October 2018).

Krenchinski, F.H., Cesco, V.J.S., Rodrigues, D.M., Albrecht, L.P., Wobeto, K.S., and Albrecht, A.J.P. 2018. Agronomic performance of soybean grown in succession to winter cover crops. Pesquisa Agropecuária Brasileira 53:909-917.

Lima-Medina, I., Gomes, C.B., Correa, V.R., Mattos, V.S., Castagnone-Sereno, P., and Carneiro, R.M.D.G. 2017. Genetic diversity of Meloidogyne spp. parasitizing potato in Brazil and aggressiveness of Meloidogyne javanica populations on susceptible cultivars. Nematology 19:69-80.

Mattos, V.S., Furlanetto, C., Silva, J.G.P., Santos, D.F., Almeida, M.R.A., Correa, V.R., et al. 2016. Meloidogyne spp. populations from native Cerrado and soybean cultivated areas: genetic variability and aggressiveness. Nematology 18:505-515.

Miamoto, A., Dias-Arieira, C.R., Cardoso, M.R., and Puerari, H.H. 2016. Penetration and reproduction of Meloidogyne javanica on leguminous crops. Journal of Phytopathology 164:890-895.

Neves, D.L. 2013. Reprodução de Pratylenchus brachyurus em diferentes gramíneas forrageiras. Global Science and Technology 6:134-140.

Oliveira, C.M., Souza Junior, I.T., Araujo Filho, J.V., Freitas, M.A., Rocha, M.R., and Petrofeza, S. 2017. Morphological, biochemical and molecular characterization of Meloidogyne spp. populations from Brazilian soybean production regions. Ciência Rural 47(5):e20160634.

Oostenbrink, M. 1966. Major characteristics of the relation between nematodes and plants. Mendelingen Landbouwhoge School 66:1-46. 
Padovan, M.P., Motta, I.S., Carneiro, L.F., Moitinho, M.R., e Salomão, G.B. 2012. Dinâmica de acúmulo de massa e nutrientes pelo milheto para afins de adubação verde em sistemas de produção sob bases ecológicas. Revista Brasileira de Agroecologia 7:95-103.

R Core Team. 2018. R: A language and environment for statistical computing. R Foundation for Statistical Computing, Vienna, Austria.

Rosa, J.M.O., Westerich, J.N., e Wilcken, S.R.S. 2013. Reprodução de Meloidogyne javanica em olerícolas e em plantas utilizadas na adubação verde. Tropical Plant Pathology 38:133-140.

Santana-Gomes, S.M., Dias-Arieira, C.R., Ferreira, J.C.A., Schwengber, R.P., and Baldisera, S.S. 2019. Reproduction of Pratylenchus zeae and P. brachyurus in cover crops. Caatinga 32:295-301.

Sharma, V., Hecker, N., Roscito, J.G., Foerster, L., Langer, B.E., and Hiller, M.A. 2018. A genomics approach reveals insights into the importance of gene losses for mammalian adaptations. Nature Communications 9:1215.

Silva, E.H., Mattos, V.S., Furlaneto, C., Giband, M., Barroso, P.A.V., Moita, A.W., et al. 2014. Genetic variability and virulence of Meloidogyne incognita populations from Brazil to resistant cotton genotypes. European Journal of Plant Pathology 139:195-204.

Taylor, A.L., and Sasser, J.N. 1978. Biology, identification and control of root-knot nematodes (Meloidogyne species). Department of Plant Pathology, North Carolina State University, Raleigh, North Carolina, USA. 